\title{
A Study on Indication for Mechanical Ventilation among Children at a Tertiary Care Hospital
}

\author{
Shashikant ${ }^{1}$, Jayaraj Patil ${ }^{2}$ \\ ${ }^{1}$ Senior Resident, Department of Pediatrics, GIMS, Gadag, Karnataka, ${ }^{2}$ Assistant Professor, Department of Pediatrics, GIMS, Gadag, Karnataka.
}

\section{Abstract}

Background: Currently, pneumonia is the sixth leading cause of death in the United States and the leading cause of death of children worldwide. The mortality rate for patients of all ages with VAP is approximately $33 \%$ to $50 \%$.Approximately $10-28 \%$ of critical care patients develop Ventilator Associated Pneumonia (VAP). It increases length of stay in ICU up to $28 \%$ and each incidence of Ventilator-associated pneumonia (VAP) is estimated to generate an increased cost of $£ 6000-£ 22000$. Mortality rate is $24 \%-71 \%$. Subjects and Methods: All patients on mechanical ventilator admitted to the pediatric intensive care unit during the prescribed study period were considered for case identification and study was prospective study. Results: Most common diagnosis at presentation in patients studied was Severe dengue 50(33.3\%), followed by Pneumonia 25(16.7\%), Sepsis 14(9.3\%). Conclusion: Most common indication for mechanical ventilation in patients studied was Severe respiratory distress (33.3\%), followed by septic shock (20\%), poor GCS (18.7\%), Dengue shock (16.7\%).

Keywords: Pneumonia, Ventilator-Associated Pneumonia, Severe Respiratory Distress.

Corresponding Author: Dr. Jayaraj Patil, Assistant Professor, Department of Pediatrics, GIMS, Gadag, Karnataka.

Received: January 2019

Accepted: February 2019

\section{Introduction}

Healthcare-associated pneumonia was the most common HAI in five studies6, and second only to bacteremia in another two reports. ${ }^{[1]}$ The range of VAP incidence density rates in both children and neonates is large. Rates as low as $1 / 1000$ ventilator-days and as high as 63/1000 ventilatordays have been reported .The incidence follows a geographical distribution and depends on the type of hospital and the country income level. ${ }^{[2]}$

A surveillance study from the International Nosocomial Infection Control Consortium (INICC) identified higher VAP rates in academic compared to nonacademic hospitals. ${ }^{[3]}$ The same study reported higher rates in lowermiddle-income compared to upper-middle income countries. Extreme PICU rates have been reported from India (36.2\%) and Egypt (31.8/1000 ventilator days). ${ }^{[4]}$ Surveys in the USA and Germany found consistently lower rates. However, high rates were reported also by high-income countries. A European multicenter study found that $23.6 \%$ of children admitted to a PICU developed VAP. An Italian study identified $6.6 \%$ children with VAP among 451 on mechanical ventilation, and a mixed PICU Australia identified $6.7 \%$ children with VAP among 269 on mechanical ventilation. ${ }^{[5]}$

In the PICU, $20 \%$ of nosocomial infections are VAP, with an incidence of 4 to 44 per 1000 intubated children. VAP is a marked health risk for hospitalized infants and children. It is one of the top causes of HAI in the PICU, accounting for $18 \%$ to $26 \%$ of all HAIs in the unit and resulting in a mortality rate of about $10 \%$ to $20 \%$.VAP is associated with increased mortality and morbidity, increased length of hospital stay, and high health care costs. ${ }^{[6]}$

Currently, pneumonia is the sixth leading cause of death in the United States and the leading cause of death of children worldwide. The mortality rate for patients of all ages with VAP is approximately $33 \%$ to $50 \%$.

Approximately 10-28\% of critical care patients develop Ventilator Associated Pneumonia (VAP). It increases length of stay in ICU up to $28 \%$ and each incidence of Ventilatorassociated pneumonia (VAP) is estimated to generate an increased cost of $£ 6000-£ 22000$. Mortality rate is $24 \%$ $71 \% .^{[7]}$

Rates of pneumonia are increased 6- to 21-fold for intubated patients and show a further rise with the duration of mechanical ventilation. The incidence of VAP ranges from 6 to 52 cases per 100 patients, depending on the population studied. Crude rates of VAP are usually 1 to $3 \%$ per day of intubation and mechanical ventilation. ${ }^{[8]}$

Rates per 1,000 ventilator days provide the best comparison. In the National Nosocomial Infections Study, rates of VAP varied from 5 cases per 1,000 days in pediatric patients to 35 cases per 1,000 days in patients with thermal injury. Overall rates are most commonly 10 to 15 cases per 1,000 ventilator days for ICU patients, depending on the population studied. Also, rates are generally higher in surgical ICU patients than in medical ICU patients. ${ }^{[9]}$ 


\section{Subjects and Methods}

All patients on mechanical ventilator admitted to the pediatric intensive care unit during the prescribed study period were considered for case identification and study was prospective study.

\section{Sample Size:}

150 children aged between 1 month and 16 years

\section{Sampling procedure:}

Consecutive patients in pediatric intensive care unit on mechanical ventilator who developed pneumonia fulfilling inclusion criteria were studied.

\section{Inclusion criteria:}

The children aged between 1 month and 16 years who are included in this study are those who are on mechanical ventilator for more than 48 hours

\section{Exclusion Criteria:}

Patients who developed respiratory infections in less than 48 hours of mechanical ventilation, those who are discharged from PICU in less than 48 hours or died within 48 hours are excluded.

Children of Parents who have not given consent

\section{Methods of Study:}

All children who are admitted in PICU and mechanically ventilated for more than 48 hours as per definition in inclusion criteria are investigated clinically, radiologically and bacteriologically to determine presence of pneumonia and isolate causative microorganism. The study also considered the presence of comorbid conditions like $\mathrm{CP}$, CHD, hematological disorders SEIZURE disorders.

\section{Results}

Table 1: Indication for mechanical ventilation in patients studied.

\begin{tabular}{|l|l|l|l|}
\hline $\begin{array}{l}\text { Indication for } \\
\text { mechanical } \\
\text { ventilation }\end{array}$ & \multicolumn{2}{|l|}{ Gender } & \multirow{2}{*}{ Total } \\
\cline { 2 - 3 } & Female & Male & \\
\hline $\begin{array}{l}\text { Severe respiratory } \\
\text { distress }\end{array}$ & $28(38.9 \%)$ & $22(28.2 \%)$ & $50(33.3 \%)$ \\
\hline Septic shock & $18(25 \%)$ & $12(15.4 \%)$ & $30(20 \%)$ \\
\hline Dengue shock & $9(12.5 \%)$ & $16(20.5 \%)$ & $25(16.7 \%)$ \\
\hline Hypovolemic shock & $6(8.3 \%)$ & $4(5.1 \%)$ & $10(6.7 \%)$ \\
\hline Poor GCS & $8(11.1 \%)$ & $20(25.6 \%)$ & $28(18.7 \%)$ \\
\hline Respiratory failure & $2(2.8 \%)$ & $2(2.6 \%)$ & $4(2.7 \%)$ \\
\hline Cardiogenic shock & $1(1.4 \%)$ & $2(2.6 \%)$ & $3(2 \%)$ \\
\hline Total & $72(100 \%)$ & $78(100 \%)$ & $150(100 \%)$ \\
\hline P=0.146 & & & \\
\hline
\end{tabular}

Most common indication for mechanical ventilation in patients studied was Severe respiratory distress (33.3\%), followed by septic $\operatorname{shock}(20 \%)$, poor GCS (18.7\%),Dengue $\operatorname{shock}(16.7 \%)$

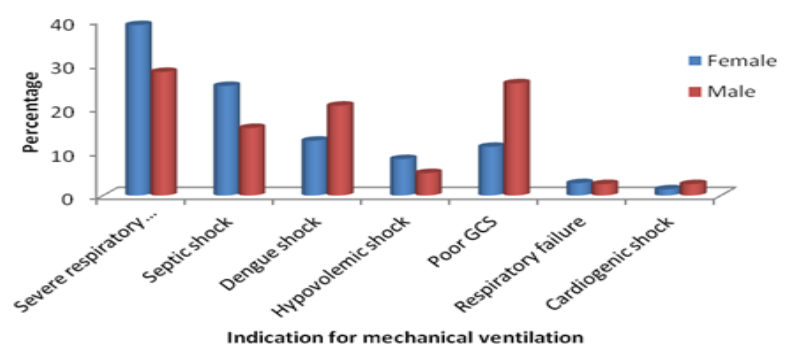

Figure 1: Bar diagram showing Indication for mechanical ventilation in patients studied

Table 2: Diagnosis at Presentation in patients studied.

\begin{tabular}{|l|l|l|l|}
\hline \multirow{2}{*}{$\begin{array}{l}\text { Diagnosis at } \\
\text { Presentation }\end{array}$} & \multicolumn{2}{|l|}{ Gender } & Total \\
\cline { 2 - 3 } & Female & Male & \\
\hline Severe dengue & $26(36.1 \%)$ & $24(30.8 \%)$ & $50(33.3 \%)$ \\
\hline Pneumonia & $14(19.4 \%)$ & $11(14.1 \%)$ & $25(16.7 \%)$ \\
\hline Sepsis & $9(12.5 \%)$ & $7(9 \%)$ & $16(10.7 \%)$ \\
\hline AGE with shock & $5(6.9 \%)$ & $9(11.5 \%)$ & $14(9.3 \%)$ \\
\hline CHD in failure & $3(4.2 \%)$ & $2(2.6 \%)$ & $5(3.3 \%)$ \\
\hline $\begin{array}{l}\text { Acute bacterial } \\
\text { meningitis ABM }\end{array}$ & $2(2.8 \%)$ & $4(5.1 \%)$ & $6(4 \%)$ \\
\hline Asthma & $0(0 \%)$ & $2(2.6 \%)$ & $2(1.3 \%)$ \\
\hline Seizure disorder & $4(5.6 \%)$ & $5(6.4 \%)$ & $9(6 \%)$ \\
\hline Poisoning & $2(2.8 \%)$ & $2(2.6 \%)$ & $4(2.7 \%)$ \\
\hline Snake bite & $4(5.6 \%)$ & $2(2.6 \%)$ & $6(4 \%)$ \\
\hline Tubercular meningitis & $0(0 \%)$ & $4(5.1 \%)$ & $4(2.7 \%)$ \\
\hline Thalessemia/hemophilia & $3(4.2 \%)$ & $6(7.7 \%)$ & $9(6 \%)$ \\
\hline Total & $72(100 \%)$ & $78(100 \%)$ & $150(100 \%)$ \\
\hline
\end{tabular}

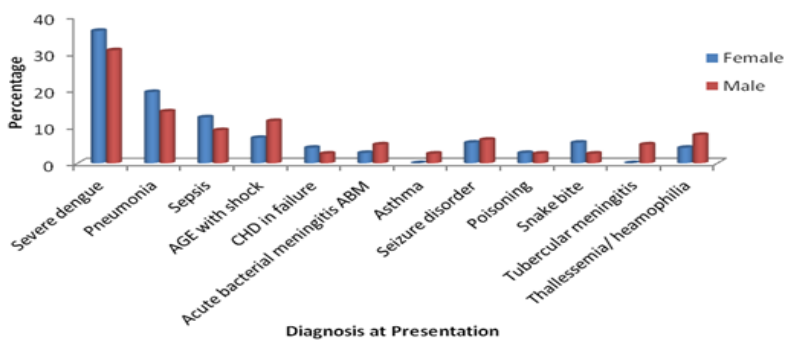

Figure 2: Bar diagram showing diagnosis at Presentation of patients studied

Most common diagnosis at presentation in patients studied was Severe dengue 50(33.3\%), followed by Pneumonia $25(16.7 \%)$, Sepsis $14(9.3 \%)$.

Table 3: Indication for mechanical ventilation in patients with VAP

\begin{tabular}{|l|l|l|l|}
\hline $\begin{array}{l}\text { Indication for } \\
\text { mechanical } \\
\text { ventilation }\end{array}$ & \multicolumn{2}{|l|}{ VAP Developed } & Total \\
\cline { 2 - 3 } & No & Yes & \\
\hline $\begin{array}{l}\text { Severe respiratory } \\
\text { distress }\end{array}$ & $31(36 \%)$ & $19(29.7 \%)$ & $50(33.3 \%)$ \\
\hline Septic shock & $14(16.3 \%)$ & $16(25 \%)$ & $30(20 \%)$ \\
\hline Poor GCS & $15(17.4 \%)$ & $13(20.3 \%)$ & $28(18.7 \%)$ \\
\hline Dengue shock & $18(20.9 \%)$ & $7(10.9 \%)$ & $25(16.7 \%)$ \\
\hline Hypovolemic shock & $2(2.3 \%)$ & $8(12.5 \%)$ & $10(6.7 \%)$ \\
\hline Respiratory failure & $3(3.5 \%)$ & $1(1.6 \%)$ & $4(2.7 \%)$ \\
\hline Cardiogenic shock & $3(3.5 \%)$ & $0(0 \%)$ & $3(2 \%)$ \\
\hline Total & $86(100 \%)$ & $64(100 \%)$ & $150(100 \%)$ \\
\hline $\mathrm{P}=0.049 *$ Significant, Chi-Square test & & \\
\hline
\end{tabular}




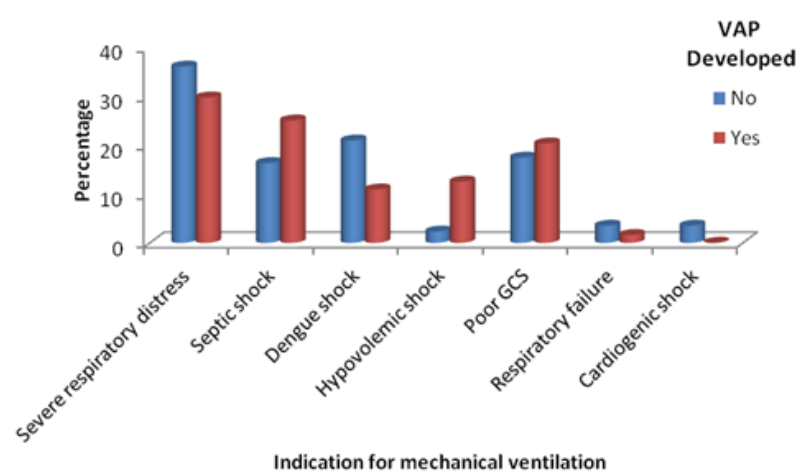

Figure 3: Bar diagram showing Indication for mechanical ventilation in patients with VAP

Most common indication for mechanical ventilation in VAP patients was Severe respiratory distress 19(29.7\%), Septic shock 16(25\%),Poor GCS 13(20.3\%)

\section{Discussion}

Mechanical ventilation is the cornerstone for the management of critically ill children in intensive care setting. This modality has its own complications and hazards. One such complication is the chance of developing pneumonia termed the ventilator-associated pneumonia (VAP). ${ }^{[10]}$ Ventilator-associated pneumonia is defined as pneumonia occurring after the patient has been on mechanical ventilator for more than 48 hours. VAP is different from community acquired pneumonia not only from etiological point of view but also in context of its pathophysiology, risk factors, management strategies and outcome. ${ }^{[11]}$

Diagnosis of VAP has been a subject of on-going debate. High clinical suspicion along with radiological examination and culture of respiratory secretions are required for the diagnosis of VAP.

Amongst the challenges in any intensive care settings, curtailing nosocomial infections like VAP is an important issue. The prevalence of VAP in different setups varies. It is important to identify the burden of VAP in any setup, so that prevention strategies can be implemented and strengthened. VAP is not only associated with increased mortality but also increases with the length of ICU stay, the cost of treatment and the chances of ventilator dependence. Various risk factors have been identified that may predispose to the development of VAP. ${ }^{[12]}$

As with other nosocomial infections, the microbiology of VAP may vary from one centre to the other and certainly the susceptibility pattern to antibiotics do vary not only from unit to unit but may show changing trend within a unit from time to time. ${ }^{[13]}$

\section{Conclusion}

Most common indication for mechanical ventilation in VAP patients was Severe respiratory distress 19(29.7\%), Septic shock 16(25\%), Poor GCS 13(20.3\%)

\section{References}

1. Fabregas N; Torres A, El-Ebiary M; Ramirez J: Hernandez C R: Gonazalez J; et al Histopathologic and Microbiologic Aspects of Ventilator-associated Pneumonia. Anesthesiology 1996:84(4) : 760771

2. Fabregas N: Ewig S: Torres A: Ebiary M: Ramirez I: puig de la Bellacasa: Bauer T: Cabello H. Cabello H. Clinical diagnosis of ventilator associated pneumonia revisited comparative validation using immediate postmortem lung biopsies. Thorax 1999 : 54(10):867-873

3. Trivedi TH, Shejate SB. Yeolekar ME. Nosocomial pneumonia in Medical intensive care unit. JAPI 2000:48: 1070-107,

4. Schurink CA, Van Nieumwenhoven CA, Jacobs JA, Rozenberg-Arska M, Joone HC, Buskens E, Hoepelman AL, Bonten MJ. Clinical pulmonary infection score for ventilator associated pneumonia: accuracy and inter observer variability. Int Car Med 2004 Feb: 30(2): 217-24

5. Fagon JY. Chastre J, Hance A J et al. Evaluation of clinical judgement in the identification and treatment of nosocomial pneumonia in ventilated patients. Chest 1993: 103:547-553.

6. Wunderink RG. Woldernberg LS, Zeiss et al. The radiologic diagnosis of autopsy -proven ventilator-associated pneumonia. Chest 1992: $101: 458-63$.

7. Hill JD, Ratloff JL, Parrot JC et al. Pulmonary pathology in acute respiratory insufficiency: lung biopsy as a diagnostic tool. J Thorax Cardiovasc Surg 1976:71:64-71.

8. Nader Kamangar, Christina Rager- Pnemonia, http//www. Emedicine. Medscape.com/article/300157-over review.

9. Meduri GU, Chastre J. The standardization of bronchoscopic techniques for ventilator-associated pneumonia. Chest 1992: 1 02(SUPPL):557S-564S.

10. Chastre J, Fagon JY. Invasive diagnostic testing should be routinely used to manage ventilated patients with suspected pneumonia. Am J Respir Crit Care Meed 1994: 150:570-574

11. Girou E, Schortgen F, Declaux C, Christian BB, Francois B, Yannick L. Association of noninvasive ventilation with nosocomial infection and survival in critically ill patients. JAMA 2000:284:2361-2367

12. Iregui M, Kollef MH. Prevention of ventilator-associated pneumonia: selecting interventions that make a difference. Chest 2002:121:3:679. 681.

13. Cook DJ, Walter SD, Cook RJ, Lauren EG, Gordon HG, David Let al: Incidence of and risk factors for ventilator-associated pneumonia in critically ill patients. Ann Intern Med 1998: 129:433-440. 
Copyright: () the author(s), 2019. It is an open-access article distributed under the terms of the Creative Commons Attribution License (CC BY 4.0), which permits authors to retain ownership of the copyright for their content, and allow anyone to download, reuse, reprint, modify, distribute and/or copy the content as long as the original authors and source are cited.

How to cite this article: Shashikant, Patil J. A Study on Indication for Mechanical Ventilation among Children at a Tertiary Care Hospital. Asian J. Clin. Pediatr. Neonatol.2019;7(1):8-11.

DOI: dx.doi.org/10.21276/ajcpn.2019.7.1.3

Source of Support: Nil, Conflict of Interest: None declared. 